\title{
Post-independent mainline churches in Africa (1975-2000) $)^{1}$
}

\author{
J W Hofmeyr \\ Department of Church History \\ University of Pretoria
}

\begin{abstract}
The Second World War was in many ways a watershed in African social and political development. Drafted by their colonial rulers into fighting for world democracy and freedom, Africans were inspired with determination to achieve this same goal for them. The ensuing struggle against colonialism eventually led to the independence of most sub-Saharan African countries in the 1960's. Following on the heels of the Second World War came the collapse of the whole colonial system. The only remaining factor in the liberation process was South Africa, which withdrew from the British Commonwealth in 1961 because of criticism of its apartheid policy and only became a full democracy in 1994. Because of the fact that the former colonial world was located in the southern hemisphere, the confrontation took on a north-south character. Mainline churches in post independent Africa responded in different ways to this changing configuration of the world, and in spite of secularizing trends and the resurgence of rival religions they remained as major players in the world stage.
\end{abstract}

\section{INTRODUCTION}

The wind of change that blew many African nations into political independence from the late 1950's to the 1960's turned into a gale after the Independence anthems ended. The new nation states turned into predatory states: some became one-party states; others spawned leaders who used the states as private large farms; still others mistook their states as a military barracks. Coups and counter-coups followed amidst the ideological cants about socialism. By 1975, the political map of Africa was redesigned as the inherited democratic constitutions were shredded. The new states became virtually "theological states", seeking to control every aspect of the citizens' lives. Theorists initially praised the "politics of mobilization", arguing that it was

\footnotetext{
${ }^{1}$ This article is dedicated to the recently retired professors A P B Breytenbach and P A Geyser for whom I both have great appreciation.
} 
necessary to "modernize" by curbing the inherited, divisive, politics of tribes and tongues that sported too many power nodes. Opponents yelled that it was not yet uhuru because the boils in the post-colonial period were worse than the yaws of colonialism. Between 1975 and 1990, the effects of poor leadership and militarisation of the society became daunting as economies collapsed, abuse of human rights and the ecology followed, civil society was decimated and corruption became rampant. European nations that had given huge loans to corrupt leaders moved in to collect on the debtor nations. The agent was the World Bank that used the structural adjustment program to rein in their victims and deployed NGO's to take the message into the hinterland bypassing the state apparati. Poverty hit Africa and civil wars ensued with incredible brutality as caged rats ate themselves. Something also snapped at the world scene as Soviet Russia collapsed. This gave the capitalist nations of the world, dominated by the United States of America, the leverage to intervene into the affairs of their corrupt satellites. Some thought that it was the end of history. The new powers read the riot act to the dictators and encouraged the indigenes to hold democratic assemblies for renegotiating the patterns of power. The end of the cold war ushered in the end of patronizing dictators. Admittedly, the results were mixed as many dictators either removed their military uniforms and donned civilian clothes, or permitted multi-party regimens so as to return to power in new guises. Still, the "second liberation of Africa", as pundits dubbed the process changed the nature of African politics.

Among the major changes was the return of the churches into the public space. Though maimed, they appear to have been the only survivors within the civil society. Other components of civil society such as trade unions, academics and students, professional bodies, judiciary, traditional rulers and any other restraining social force had been compromised or destroyed. This backdrop gives poignancy to the story of African Christianity in the period 1975 to the end of the millennium. What was the role of the church in the recovery process? This is the burden of this chapter.

Some think that churches that colluded with the colonial enterprise and waltzed with nationalists had lost its relevance in the public space. Others think that the churches were in fact equipped to play such an important role; that, while the colonial powers hindered rather than helped prepare the way for democratic rule after independence, such preparation often did take place within Christian missionary institutions. These were not democratic in themselves, but they inculcated democracy as the ideal form of political organization. As De Gruchy (1995:165) so clearly states: "In much of sub-Saharan Africa, the principles of unity, democracy and self-government were developed in the church long before they were even dreamed of in the state."

Following on the heels of the Second World War came the collapse of the whole colonial system. In the 1940's and 1950's all of South and South- 
east Asia gained independence and in the Middle East the old League of Nations mandates were ended. A similar process of decolonisation also occurred in the Caribbean and South Pacific islands. Between the years 1951 and 1968 all the North Africa Muslim states and most of the colonies south of the Sahara were liberated, beginning with Ghana in 1957. In 1974 and 1975 the Portuguese empire was dismantled. In 1980 Zimbabwe and in 1990 Namibia became independent. One-party states (e g Zaire, Kenya, Zambia) and socialist experiments (e g Congo, Tanzania) emerged to take their place. The only remaining factor in the liberation process was South Africa, which withdrew from the British Commonwealth in 1961 because of criticism of its apartheid policy and only became a full democracy in 1994.

\section{NEW DIMENSIONS IN MAINLINE CHRISTIANITY}

Four new dimensions of African Christianity have characterized African Christianity in the $20^{\text {th }}$ century. In 1990 , Richard Gray observed that two themes have dominated contemporary African church historiography: to tell the African's own story of the encounter with the gospel and to show Africa's contribution to world Christianity. For this second component, attention focused on the African Instituted Churches and the post - 1970 growth of Charismatic and Pentecostal spirituality. He, therefore, warned against the neglect of the developments within the mainline churches. In most African countries, these mission founded churches with $19^{\text {th }}$ century pedigrees have continued to grow. The Roman Catholic Church remains the single largest Christian group in Africa. The Anglican Communion in Nigeria has grown by over seven million in the last decade to about 17 million Anglicans out of 75 million worldwide. In 1979, the Nigerian church had sixteen dioceses, organized in a single province with a single archbishop; today it has nearly eighty dioceses, organized in ten provinces with ten archbishops. It would appear that various encapsulation strategies have ensured numerical growth and socio-political influence.

In 1998, Paul Gifford argued that the mainline churches, rather than the charismatic genres bore the brunt of social responsibility and played the most important roles in the public space from 1975 to the end of the millennium. The year 1975 is significant in African church history because the World Council of Churches held its General Assembly in Nairobi, Kenya. It signified that African Christianity has come of age and attracted world attention. In the meantime the process of decolonisation was also succeeding and in all of this a measure of solidarity was reflected with Africans during the last throes of Western domination and the denial of justice to Africans in the central and southern regions of the continent. 
First, the quarter century spanning from 1960-1985 was characterized by the implosion of the state, the attack on the dominant role of the church in the public space and the churches' various strategies for survival. The nationalism in the politics of independence turned against the church that had supported its path and trained its protagonists. Dictatorial one-party states, praetorian military juntas and the alliance with socialist ideologies reflected efforts to dislodge the vestiges of the colonial heritage. Recent scholarship argues that none of the African states was purist Marxist but the rhetoric impressed the masses to believe that an authentic African political culture and development would improve their lot. Christian churches were imaged as neo-imperialist symbols. Churches lost control of schools, hospitals and other charitable institutions. But by 1985, most economies had collapsed; poverty enveloped communities; abuse of human rights and legitimacy crises followed apace. Coups and counter coups symbolized that things have fallen apart. Aged rulers clung to power as if they were mafia godfathers. It was however eventually the change on the geopolitical front that catalyzed the rapid series of events that would bring Christianity to the center again. The collapse of the Berlin Wall, the collapse of Communist Russia and the end of the Cold War made democratic ideology popular again. The question can, therefore, be asked what was the role of the churches in the democratization process during the last quarter of the $20^{\text {th }}$ century? A strange thing happened: churches had been accused of collusion in the colonial period and silent during the predatory army regimes but suddenly their relevance in the public space was recognized in one country after another. The leaders were the only trusted ones to chair or broker the democratic experiments. Was this an illusion? Many churches not only provided leadership during the overthrow of dictators but catalyzed the process. Some of the case studies below will provide more information in this respect.

The second factor, therefore, is the significant role played by Christianity in combating racism and apartheid in Zimbabwe, Namibia and South Africa and by intervening in the civil war in Mozambique between 1986 and 1996. These interventions deserve attention because they moved beyond the cultural theology in many parts of Africa to the application of confession as a means of political engagement. The Kairos Document therefore, published in South Africa in 1986, was a major African contribution, especially as it diverged from a similar attempt by the German Christians in 1937. The support of the church for freedom fighters in Zimbabwe and Namibia paved the way for contributions in development.

Third, though ecumenism lost wind after the 1980's, African churches engaged in new co-operative ventures and used inculturation theology as a 
tool for evangelisation. It is suggested that this fact engendered growth. African churches have in the decade of 1990-2000 developed new partnership relationships with overseas mentors and new forms of local cooperation. The All Africa Council of Churches (AACC) for instance, is regaining strength. The reasons include the decline of Christianity in the West; the withdrawal of longterm missionaries; the decline in funds for large-scale cross cultural missions; theological divisions over the ordination of gays that have weakened many metropolitan churches and the realization that the center of gravity of Christianity has shifted to the southern hemisphere.

Fourth, is the entry of churches into the zone of tertiary education that used to be the purview of the state. There is an increase in the number of church related universities. It reflects an attempt by churches to regain former command posts and to re-engage the public space in the wake of the failed economies and the confidence of the states. In the period 1980-2000 many Christian groups and churches created new colleges and universities in Nigeria, Cameroon, Kenya, Ghana and Zimbabwe. It could also be argued that this dimension has been compelled by competition with the rising challenge by Pentecostal and charismatic movements who first ventured into tertiary education. These processes will be picked up in greater detail in the next chapter.

It does appear that beyond these cultural matters, mainline churches have been compelled to adjust by enlarging the space for charismatic groups in polity, liturgy and ethics. Tithing, fasting, prayer bands, healing sessions, lively music, dancing and other forms of liturgical renewal are prevalent. Among Catholics, apparitions, monastic spirituality, black rosaries and the vernacularization of liturgy have released new devotional liturgies. This trend has two imports: at one level, it has catalyzed growth by renewing the old process of indigenisation in a different key. But it has stamped African Christianity with a conservative character. The social policy on ordination of women in many churches, same-sex marriage and opposition to gays and lesbians are indications of a trend that has derailed from the liberal attitudes of the Western metropoles of these churches.

However, it is often wondered whether this conservative character of African Christianity would hinder a creative response to the scourge of HIVIAIDS that is ravaging the continent. The question arises about the churches response in the face of the threat; to what extent has it served as a pressure group to ginger the governments? The importance of this question is heightened by the noticeable laicization of the Christianity in the $20^{\text {th }}$ century. Has this trend that has changed the power and leadership structure and 
brought women to the fore influenced the style of the churches' role in the public space?

\section{SOME CASE STUDIES}

Perhaps, it would best serve to illustrate these broad trends with case studies covering four regions of the continent: west, east, central and south. In each case a different dimension of the mainline churches is being highlighted such as growth at the expense of mainline churches in West Africa (Liberia), the clout of mainline churches in East Africa (Kenya), the mainline churches as a power broker in Central Africa (Malawi), and the mainline churches' role in the transformation process in South Africa. The case studies rely on the works of contemporary scholars: Paul Gifford (1992), Ogbu Kalu (1998), Kenneth Ross (1999) and J W Hofmeyr (1994). In certain parts of Africa, the mainline churches have lost the earlier monopoly because of the growth of new Christian forms that have sprouted from within Protestant traditions. Years of monopoly created nominalism and the strategy proselytism made it impossible for the churches to evangelize and disciple the communities. Liberia sported two such cases before the Civil War that engulfed the country in the last decade. Bethel and Transcea were two different types that stole the center stage from the Methodists and Lutherans who had dominated the religious power for years, often in collusion with Roman Catholics, Episcopalians and Presbyterians.

Paul Gifford gives a graphic account of Christianity in Doe's Liberia by contrasting the locations of the imposing Episcopal Cathedral that occupies a commanding site on the hill on the main street of Monrovia and the nondescript locations of the new churches. The Episcopal cathedral is probably the biggest church building in the country, elaborately furnished, with the organ donated by the Firestone family. In 1989, the cathedral attracted about 250 worshippers to its two Sunday morning services. Just 500 yards away, on a much less impressive site, met the Transcontinental Evangelical Assembly Church (Transcea). This was founded in 1983; that is, one hundred and fortyseven years after the Episcopal Church came to Liberia. Transcea had no buildings of its own, and rented schoolrooms every Sunday. Yet by 1989 , 1600 people attended the four Sunday morning services, and the church was said to be growing at a rate of over 40 new members every week.

The Presbyterian Church was one of the first churches to come to Liberia, being established in 1833. The American missionaries later abandoned it, as they considered their foundation in Cameroon to be a far more viable proposition. Without missionary assistance, the Presbyterian Church remained very small. By 1989 it had only about 3000 members in the 
country. In 1977 a member of the Presbyterian Church went to the U S A to study. On his return in 1987 he did not return to the Presbyterian Church, but took over a young church founded the previous year, Bethel World Outreach. This church had about 120 members when he took over; by the end of 1987 the membership had increased to 250 and necessitated moving the Sunday services to the Monrovia City Hall. By late 1989 about 1200 attended the two Sunday morning services. These examples illustrate an occurrence that was becoming more frequent in Africa throughout the 1980s. Mainline churches lost members and prominence to new churches that were growing and flourishing often at the expense of the mainline churches. This overview looks at Bethel and Transcea, Liberia's fastest-growing churches in the late 1980s, in an attempt to shed light on this development within African Christianity. Needless to add, all lost in the civil war and thereby created a new ecclesiastical situation.

\section{THE CONTEXT}

Liberia is a small country situated at the southwestern point of West Africa. Its 2.5 million inhabitants in 1989 were made up of sixteen principal tribes and a small group descended from repatriate American slaves or from slaves freed from slave-ships captured on the high seas. The first slaves were brought to Liberia in 1822. The number of these repatriate slaves was never large, but descendants of this small group of repatriates (about $3-5 \%$ of the population) monopolized all political power, and from 1870 ruled the country through their True Whig Party (TWP). Politics within this settler community were extremely corrupt. Incumbent presidents used every resource to stay in power. For example, in the 1927 elections which returned President King, King was credited with 243,000 votes, and his opponent 9000 , when the total electorate comprised no more than 15,000 . In other words, the winner's majority was 17 times greater than the number of possible voters. This election won the title, in the Guinness Book of Records, as the "most bent" election of all time. Financial affairs were conducted in a similar fashion. There was a budget, but it was never adhered to. There was no system of accountability for public funds.

Firestone and other multinationals arrived after the 1920s. These multinationals contributed surprisingly little to the development of Liberia. They bought off Liberia's ruling elite, who in return for personal gain protected the companies' favorable terms, and made sure that government controls were kept to a minimum. Thus little was spent on planned expansion of the country's productive base, or on development of infrastructure. As late as the 
1960 s the country had only ten miles of paved road. The government simply dispensed patronage to the increasing numbers of its own elite.

During the presidency of William Tubman (1944-71), the patronage party state reached its limit. All government workers were required to contribute one month's salary to the TWP annually. The cult of the presidency also reached its peak in this period. Tubman subverted every institution of society to enhancing it. Real opponents were victimized and destroyed, and at election time token opponents were produced to disguise the reality of a oneparty state. He had a presidential yacht whose budget was greater than that for the country's justice system, and at one stage the appropriation for ceremonial bands surpassed the expenditure on public health.

After Tubman's death in 1971, his Vice-President William Tolbert took power. Tolbert was forced to make some changes, but the system remained fundamentally unaltered. In 1979, as chairman for that year, Tolbert was to host the annual conference of the OAU. He spent US $\$ 100$ million in constructing a conference center, and not long afterwards announced that the price of rice would have to be raised. (It was not lost on the population that the Tolbert family, as the country's biggest rice producers, would derive most benefit from such an increase). This was the final straw, and on 14 April 1979 riots broke out, with widespread looting. Tolbert assumed emergency powers, put down the riots with great force, and postponed municipal elections. When a strike was called the following March, Tolbert had the leaders arrested on the grounds that they were plotting an armed insurrection. In the early hours of 12 April 1980, two days before the trial of the alleged plotters was to begin, a group of 17 enlisted men overthrew the government, killing Tolbert and 27 others.

Initially this coup was immensely popular. People danced in the streets and greeted the news with enthusiasm. But quite early, the event was perceived from ethnic lenses as the indigenous Liberians hailed the coup as their liberation after 158 years of domination by American-Liberians. The seventeen soldiers who carried out the coup declared Master Sergeant Samuel Doe as the Chairman of the People's Redemption Council that took over the reins of government. Doe announced that he had not assumed power to repeat the oppression of the past, and indicated that he would soon return the country to civilian rule. However, it was not long before the true nature of the regime became apparent. By 1984, Doe had lost all popular support. The general feeling was that the system was unchanged: "Same taxi, different driver", and, if anything, controlled by someone even more corrupt and inept than previous rulers. 
In 1984 Doe set in motion the return to civilian rule. He immediately announced his own candidacy, and he obviously intended to win. For example, he immediately postdated a new decree of the defunct ruling council which made it a "felony of the first degree" to accuse any member of the assembly of any crime when one intended "to injure the official in his reputation, to create disharmony, spread rumors, lies and disinformation, to cause civil strife or confusions". By means of this infamous decree 88A he was making any criticism of him in the electoral campaign a criminal offence.

The ensuing election campaign was something of a charade. Doe simply banned the two leaders with the greatest following. Amos Sawyer and Bacchus Matthews were declared ineligible to take part in the election at all because of "strange and foreign ideologies against our most tested and matured of life (sic)" and "espousal of and involvement in ideologies foreign to Liberia", respectively. Three parties besides Doe's National Democratic Party of Liberia were eventually permitted to contest the election. On the Election Day, 15 October 1985, there was a massive turnout. Voters queued for hours, and polling hours had to be extended from $6 \mathrm{pm}$ till 11pm. Observers soon announced that the Liberian Action Party was well in the lead, and would have a majority over all the other parties put together. So Doe's appointee as chairman of the elections' commission halted the count in the early morning of 16 October, and insisted that all votes be brought to Monrovia for counting. He established a new commission (packed with Doe's supporters) to count the votes. When the "official" results were announced on 29 October, Doe was credited with $50.9 \%$ in the four-way race for the presidency. The gloom that descended on Liberia that day was compared to the national gloom and stupefaction that enveloped the USA the day President Kennedy was assassinated.

The elections were barely over and the opposition parties were still protesting, when on 12 November 1985 there was a coup attempt. Initially it seemed to have succeeded, and there was unrestrained jubilation and dancing in the streets. The coup however lost momentum, and later in the day Doe came on the radio to announce that he was still in charge. Unfortunately, the dancing in the streets earlier had been recorded on video. Doe took revenge with indiscriminate repression, arrests, intimidation, torture and murder.

Doe was inaugurated as president of the second republic in January 1986. In reality, nothing had changed since the Tubman/Tolbert days, except that in many respects the regime was more blatant in its abuses and more inept. The new regime continued to make a mockery of the independence of the legislature and the judiciary. Freedom of speech was severely curtailed. 
Newspapers were threatened and closed at will. The community radio station ELCM was closed indefinitely in June 1989. And Doe continued to eliminate opponents, usually by discovering coup attempts, which would lead to the execution of alleged plotters, either with or without a form of trial. By 1988, only nine of the 17 soldiers involved in the 1980 coup were still alive. In all this greed, mismanagement, and single-minded pursuit of power, the economy disintegrated. Firms went bankrupt; unemployment soared. Liberia's GDP declined by an average of about $2.8 \%$ annually in $1980-85$, and continued to decline. Some revenues (for example, from logging) did not go into the national revenues at all; they went to Doe's private funds, to be dispensed as he saw fit. Misappropriation of funds was rife. Corruption crippled the system at every level. Immigration functionaries required a bribe before they would stamp a passport. School inspectors could threaten to close a school unless they were paid a bribe. Soldiers and police on duty at roadblocks required bribes to let passengers through. When corruption at the top was so shameless, there was no discouragement at lower levels.

Of course, the general deterioration affected everyone. Food and fuel shortages became common. The infrastructure crumbled. Roads in the interior became impassable during the rains, and even in Monrovia roads were often impassable. Public buildings fell into disrepair. (i e, the goal in Greenville simply collapsed while prisoners were asleep; they escaped). Education regressed in all sorts of ways. A World Bank study in 1988 noted that Liberia had a literacy rate of 35\%. Between 1982 and 1986 public primary school enrollment dropped 270\%, from 109681 to 80048 students. The total percentage of expenditure on education in 1980 and 1983 was $24.3 \%$ and $13.2 \%$ respectively - a $45 \%$ decrease in the government's commitment to education. Teachers were not paid for months on end; books were scarce. The state of the health service became just as critical. In many regions there were no drugs at all between 1982 and 1985. Leprosy was on the increase 482 new cases were reported in 1988 - and the TB program simply collapsed. Monrovia's teaching hospital became a national disgrace.

This was the situation when on Christmas Eve 1989 Charles Taylor launched the invasion that led to the death of Doe on 10 September 1990 and the almost total destruction of Liberia that had always prided itself on being a Christian country. President Tubman had been a prominent Methodist. President Tolbert was president of the Liberian Baptist convention for the fifteen years prior to his death. (In fact he had been elected the $11^{\text {th }}$ President of the Baptist World Alliance in 1965). Doe also had joined the Baptist church. Liberia is a case study where the church was at the helm of corrupt public role because the mainline churches had always enjoyed a privileged position. 
However, as the socio-economic situation deteriorated, there occurred a veritable explosion of new churches. The most prominent among these churches were the two we will now consider.

\section{BETHEL AND TRANSCEA}

Bethel was founded in January 1986 by a Liberian (a Kru), who had studied at the Moody Bible Institute in Chicago. As a fultime employee of Liberia's Telecom, he had limited time to devote to the church. He needed someone with more training to pastor the church. He thus approached a Liberian completing a DMin (in children's city ministry) at Oral Roberts University, Tulsa. This Liberian, a former Presbyterian, returned and effectively took over Bethel in July 1987 when the church numbered about 120 members and was meeting in a schoolroom. Under its new pastor (the original founder soon left for Oral Roberts University himself) the church grew rapidly; by November 1987 it numbered about 250 and shifted to Monrovia's City Hall. By late 1989 it was attracting 1200 to its two services each Sunday morning. It had also started a daughter church across the St Paul River in Virginia County. Moreover, Bethel's influence extended beyond those who attended its services. The church attracted considerable publicity through its spectacular growth and high-profile activities. The pastor rapidly became one of the prominent churchmen in the city. He was one of those behind the establishment of the Liberia Fellowship of Full Gospel Ministers, and was made its first president. This body was established to promote Bethel's style of Christianity. The Bethel pastor's own status ensured that this body allowed him to exert a kind of hegemony over twenty or thirty similar churches.

Transcea, on the other hand, was founded in 1982 in Ghana by a 21year old Ghanaian Presbyterian. He was then studying law by correspondence, and won a scholarship to study law at Oral Roberts University in Tulsa. On his way to the USA he passed through Liberia in August 1983; here he said the call became too strong, and he stayed and began Transcea. Initially, he started a very strong charismatic ministry that featured all signs such as healing of the dumb and deaf, and intensive prayer and Bible study. Later, he moved back to his Calvinist roots in 1987 privileging holiness of life and asceticism. He spoke rather bitterly of the charismatic movement, calling it pure "salesmanship" which leads to no understanding or commitment on the part of its members, whose lives are normally no different from those of unbelievers. Privately he would talk of "all the rubbish I learned from that lot." At the time of this change of direction he abolished drums and dancing in the church as inconsistent with the Bible. He replaced them with an 
organ and intended introducing other biblical instruments (like flute and trumpet) as money allowed.

As another part of this change, he abolished praying in tongues in church; after 1987 members could pray in tongues at home in private, but not in public. Similarly, prayer for healing was restricted to after rather than during the service. Although the pastor expected God to meet the needs of his people, he said he ceased preaching the gospel of prosperity. At the same time he severed links with his original churches in Ghana, and a new one established in Sierra Leone. In Liberia he resisted all attempts to draw him into charismatic fellowships and maintained his isolation. In this Transcea was unlike Bethel, which, as we have seen, worked to establish almost a hegemony over similar churches. Because the pastor was a Ghanaian and an English speaker, Transcea was not a tribal church, nor did it cater for Americo-Liberians.

Transcea grew enormously. By 1989 it had three small branches outside Monrovia, in Bong Mine, Firestone and Kakata, and a Sunday afternoon service at Monrovia's New Kru Town drew about 120, but its real strength was evident at its four services at Monrovia's Matilda Newport High School every Sunday. By September 1989 it had 1600 attending these services, and was growing by 40-60 every Sunday. The pastor was expecting to have 2000 members by the end of 1989. Of these new members the pastor estimated that $50 \%$ were uncommitted members of other churches, $50 \%$ were new Christians. Other public services during the week included a Bible class, and a miracle service every Saturday afternoon, and from September 1989 a miracle revival each Wednesday evening in Monrovia's suburb of Paynesville. (Gifford, 1992:33-40).

\section{THE CHURCH AS AGENT OF DEMOCRACY IN EAST AFRICA}

There is a certain irony in the Liberian case study, namely, that the church did not challenge the government's social policies. Indeed, the mainline churches possess enormous clout due to their longevity, proselytism with social and charitable institutions, control of education and close contact with ruling groups. As Kalu states "her declarations can influence the national ethos, and her pulpits can be used to educate the members about particular issues. Church lobby or pressure group tactics can be quite effective. Civil disobedience and participation in revolution are exemplified in the careers of some churches in Africa (Kalu 1998:201). Recent studies have focused on the role of The Church of the Province of Kenya (Anglican, CPK). It was the 
official church of British colonial power and enjoyed a relatively privileged position buttressed by a physical presence in people's every day life.

It acquired a powerful material base and tremendous organisational capacity. Even when Bishop Henry Okulu advocated a democratic power structure, the official theology still prescribed a constructive collaboration with the powers that ruled. Controversy surfaced more visibly under Arap Moi in 1982 after the coup attempt. A coercive centralising process started. Represssive state surveillance and crackdowns followed apace. Varied forms of popular protest emerged among the wanachi but Moi insisted on destroying all forms of opposition. He claimed to have played this role under Mzee Kenyatta. This is how, willy-nilly, by 1990 the onus of opposition was foisted upon the PCK.

Two issues were central: a critique of the structure of power advocating a shift from one-party to a multi-system polity; and the politics of transition which raised to the fore the issue of pauperisation. Sabar-Friedman's discourse and analysis traces the contours of public debate up to the formation of the multi-party structure. The roles of the ruling elite, the press, the fact of ethnicity all join to complicate the scene. There is data on the roles of other churches, such as the brutal odyssey of Timothy Njoya, a Presbyterian minister. The Roman Catholic bishops in July 1993 launched an attack on Moi. Equally noteworthy has been the career of Dr David Gitari, Bishop of Kirinyaga. His sermons have become a homiletic form of doing political theology. Graham King's study considers the use of Scripture in some of Gitari's sermons and in litanies and plays by students.

The twenty-four printed sermons of Bishop Gitari provide a good example of political theologising in contemporary Africa - an area of scholarly inquiry for African Theology in the twenty-first century. In the end, however, ethnic conflicts within the churches and immaturity complicated the squabble among the opposition, giving Moi an opportunity to retain power in the changed circumstances (Kalu 1998:201).

Another example of the mainline churches as power broker in the hub of restoration of democratic governance is from Malawi. "The victory of the multi-party advocates in the National Referendum of June 1993 led to the legalising of opposition political parties and the promise of a General Election which was finally held on 17 May 1994. In the struggle for legitimacy between government and opposition during this period the churches played an important role as power brokers. By virtue of the fact that they were not seeking political office for themselves church leaders came to exercise a distinctive influence on the unfolding political drama. The Malawi Congress Party (MCP) government had long been aware of the ideological power of 
religion in the political realm. Systematically and successfully over many years it had pressed the churches into service to supply it with religious legitimation. Much was made in the party propaganda of the fact that Banda was an elder of the Church of Scotland. Indeed the issue of the Daily Times which reviewed the year 1991 singled out as the highlight of the year the "triumphant moment" in which Dr Banda had been presented with a scroll to mark the $50^{\text {th }}$ anniversary of this ordination to the eldership. It was a major blow, in the aftermath of the Pastoral Letter, when the Church of Scotland made it clear it no longer regarded Banda as an active elder. The extent to which the government was stung into serious over-reaction at that time is a measure of how much it depended on the unquestioning support of the church.

This was further indicated, after almost all churches had rallied behind the work of the Public Affairs Committee (PAC), by the importance which the government attached to the continuing support of the Nkhoma synod - the Central Region section of the CCAP which had strong historical links with the MCP leadership. As it struggled to retain an air of legitimacy it turned to ministers of the Nkhoma Synod to officiate at government functions and to generally show solidarity with the MCP. This they were willing to do especially during the early referendum period. Belatedly the Nkhoma Synod did seek to draw back from its unqualified support of the MCP government with a statement in April 1993 that "the Synod believes that genuine Christians can support either side of the referendum question without violating the genuine ideals and principles of Christianity." This attempt at "neutrality" did not convince the other churches that saw it simply as an evasion of the demands of the gospel. It did, however, leave the government even more bereft of the church endorsement on which it had depended in the past. In desperation the MCP attempted to supply its own religious legitimation. When it launched its campaign newspaper, the Guardian Today, it was striking to note how many articles were devoted to portraying the MCP as having a divine mandate. This was epitomized by a cartoon series on the theme "MCP Points to God!; MultiParty-Horns of the Devil!" Such desperate propaganda revealed how much the MCP government had depended on the legitimation that it had received from the churches in the preceding years. Once the churches had broken out of that ideological captivity, the MCP government faced a crisis of legitimacy that it was unable to surmount. On the other hand, the emergent opposition was able constantly to appeal to the prophetic critique of the churches as justification for its political initiative. Indeed, the manifesto of the United Democratic Front, the first to be issued by an opposition party after the referendum, began with a quotation from the Lenten Pastoral Letter and stated that the movement for political reform had been initiated in response to 
the call from the Catholic Bishops. Occasions such as the Requiem Mass held in May 1993 for four politicians who were widely believed to have been assassinated by government agents ten years earlier, were highly charged politically and very damaging to the credibility of the government.

It was no surprise that, when UDF leader Bakili Muluzi made his victory speech after the National Referendum, he went out of his way to thank the churches: "In particular, I would like to single out the seven Catholic Bishops and the [Presbyterian] Blantyre Synod." In a country where the Christian faith is highly esteemed by a large proportion of the population, the legitimacy which the churches bestowed on the opposition movement, in face of government attempts to brand its leaders "dissidents" and "confusionists", was a considerable factor in enabling the forces of change to succeed. At the popular level a significant factor was that many church songs were adapted to give expression to the movement for political liberation. Church choirs are very popular among young people and they took their church music as a medium for expressing a particular political message.

So Ndiri ndi Bwenzi Langa Yesu (I have my beloved friend Jesus) became Ndiri ndi Bwenzi Langa Muluzi (I have my beloved friend Muluzi - the leader of the UDF). In this way there occurred at the popular level a conflation of Christian belief with the call for political reform. Particularly influential were the songs of Paul Banda and the Alleluya Band, a well-known Malawian pop group. In a powerful song like Tyamike Chauta (Let us praise God) they played on the symbols of the opposing sides in the referendum - the hurricane lamp of the multi-party side and the black cock of the one-party side - to suggest an identification of multi-party with the light of Jesus Christ and of one-party with the darkness of Satan. A notable feature of the ideological struggle was that the opposition began to argue that Rev John Chilembwe, a Baptist pastor, not Ngwazi Kamuzu Banda, was the father of Malawian politics. There were good historical grounds for doing so since Chilembwe led an armed rising against British colonial rule in 19l5. A popular song during the campaign period, entitled Kuno Kwathu ku Malawi, suggested that just as Chilembwe fought against the oppression of the colonialists so Muluzi would fight against the oppression of Dr Banda and the MCP. It was notable that when the new government announced the public holidays for the 1995 calender, Kamuzu Day was missing and Chilembwe Day had been introduced!

For the churches there was a struggle involved in adapting to the new role as power-broker. On the one hand, some church leaders became so involved in the political arena that they eventually left the church ministry in order to devote themselves to politics. From Blantyre Synod Rev Peter Kaleso 
became a Vice-President before later joining the UDF and becoming Ambassador to South Africa. From Livingstonia Synod Aaron Longwe embarked on full-time human rights work with the newly established Foundation for Justice, Peace and the Integrity of Creation. From the Baptist Church Emmanuel Chimkwita became first a shadow cabinet minister and parliamentary candidate then later Ambassador to Mozambique. In each case it had to be made clear that they were acting as politicians in their own right and no longer as representatives of their churches. On the other hand, there were those who believed that the churches became too detached from the political process, especially in the post-referendum period. When legislation was being passed in Parliament to establish the National Consultative Council and the National Executive Committee as the bodies that would oversee the transition to a multi-party political system, the Public Affairs Committee (PAC) declined to be represented and thus left the process of reform entirely in the hands of the political parties. This allowed the government later to claim that PAC was a body that had a role only in the pre-referendum period and affirming very clearly that "PAC is a relevant body and there is need for its continuity now and after the General Elections. The church being the Conscience of Society shall continue to play his noble and prophetic role .... The formation of NCC and NEC does not mean the non-existence of PAC. PAC is here to stay for ever in Malawi." In the run-up of the General Election PAC was particularly active in working to avoid the "Kenyan scenario" of a divided opposition allowing the old regime to remain in power. In civic education and election monitoring the churches remained by far the most effective organisation and contributed significantly to the General Election being a very peaceful and highly efficient exercise.

On 17 May 1994 Bakili Muluzi, leader of the UDF, won Malawi' s first democratic Presidential election while in the new multi-party Paliament UDF won 85 seats, MCP 56 and AFORD 36. Anastasia Msosa, the Chairperson of the Electoral Commission, commented that: "When you use the church, usually it is very effective. During the elections, if you appealed through the church it produced quick and effective results. The political change was positive in a short time because it came through the church." To many Christians the peaceful transition to democracy was testimony to the power of prayer since, above all, the churches had engaged with the political process by turning to God and calling for divine help and guidance. In terms of the political process, the Public Affairs Committee made the church a significant force as a power broker. Integral to this development was the unity of the various groupings which allowed the PAC Secretary to sign himself in 
communications with government: "On behalf of the country's Religious Communities I beg to remain, Yours very sincerely, Misanjo E. Kansilanga."

A new kind of power would now be exercised in Malawi. It would be accountable - to the opposition in Parliament, to the free press, to the freedom of expression and freedom of association now enjoyed by the people at large. Would it also be accountable to God? When Bakili Muluzi accepted the office of President he immediately invited the churches to offer correction to his government whenever it might stray from the path. This gave the churches the opportunity to subject the exercise of power in Malawi to the Gospel of Jesus Christ. How would they respond? History suggests that the church's social witness is strongest when there is some great evil to be confronted. Where the church often falters is when the great evil has been defeated and it is time for social and political reconstruction. What role would the churches play in shaping the exercise of power in the new Malawi? Answers to such questions may be sought by examining the prevailing understanding of power with the life of the churches and, especially, by attending to those who have been most excluded from power - the poor, the women, the young people, the prisoners, the Muslims, the Jehovah's Witnesses" (Ross 1999: 35-40).

\section{CHURCHES IN THE TRANSFORMATION PROCESS IN SOUTH AFRICA}

The Rustenburg Conference of churches which took place in November 1990 can justifiably be described as one of the most decisive events in recent South African church history, involving both mainline and other churches. About 230 church leaders from 80 denominations and 40 para-church organisations met in an attempt to work towards a united Christian witness in a changing South Africa. In many ways the Rustenburg Conference was the response of a very large body of South African churches to the political changes that began on 2 February 1990. This meeting was extraordinary in that it brought together a cross-section of all the traditions of the churches in South Africa. It is estimated that the meeting was representative of more than $90 \%$ of the South African Christian community. This constitutes more than $70 \%$ of the total population of the country.

Rustenburg not only saw the Dutch Reformed Church publicly acknowledging its involvement in and membership of a political system of discrimination, but it also took some important steps towards a change of mind-set and attitude. Also the first steps in a process of forgiveness and restitution were taken. A new society can hardly be born if the pains and 
frustrations of the past are not attended to. All this not only creates hope, but also the possibility of again living in faith.

In many ways the Rustenburg Conference will go down in history as the "Conference of Confessions". In response to the prompting of the Holy Spirit the greater part of the church in South Africa repented their past and thereby set a new course for the future. It appears that restitution was a far more difficult issue for the Rustenburg Conference than were confession and forgiveness. It should be remembered that the dominant view of reconciliation in South Africa was quite often the view of the dominant. The task the church now has to face is to rediscover and preach good news to all, this includes the poor and the oppressed.

The Rustenburg conference fully realised that the churches in South Africa have a great responsibility to combat the effects of apartheid. For decades to come, South Africa will have to battle to remove its effects in many spheres of life. Some of the most important are national health and welfare, unemployment, education, and housing where the effects of apartheid have been felt most by the oppressed. In 1991 a representative group of church and business leaders came together to launch an important national peace initiative. On 14 September 1991 a National Peace Accord, signed by 23 organisations (including the ANC and the National Party) entrenched, for the first time, the principle of full accountability on the part of both the state and political parties for the actions of their servants or supporters. This provided an example of what could be done through sufficient compromise and goodwill.

In the spirit of the National Peace Accord the South African Council of Churches arranged a training conference with the theme "Empowerment for Reconciliation with Justice" (ERJ). The ultimate aim of this conference was to build a national network of trainers, mediators, and negotiators to contribute to the work of the National Peace Accord. In the keynote opening address of this conference which took place early in 1992, Bishop Stanley Mogoba, at that time the presiding bishop of the Methodist Church of Southern Africa, stated that the convention for a Democratic South Africa (Codesa), the National Peace Accord, and the finest constitution devisable would remain mere words if there was no reconciliation. According to him it is commonly believed that reconciliation is an easy way out, however, nothing is further from the truth; in fact, the path to reconciliation is the more difficult one. It requires enabling a polarised people with deep feelings of hatred, fear, and distrust to find one another and to live together in the one country.

A wide range of churches were involved in the ERJ. Initially, with the encouragement of church leaders such as Archbishop Desmond Tutu, 
Archbishop Denis Hurley, and Bishop Stanley Mogoba the Anglican, Roman Catholic, and Methodist Churches together with church-related organisations like Africa Enterprise, Diakonia, and Wilgespruit Fellowship Centre, came together to explore the development of a consultative process. After consultation and deliberation, individuals from the Dutch Reformed Churches, the Pentecostal Churches, and the African Independent Churches were drawn into the ERJ initiative.

The ERJ was a Christian initiative that sought to enable South Africans to understand and address conflict and violence in the South African society. This was achieved in different ways: by organising consultations that seek to equip participants in conflict analysis skills and consciousness raising, conflict handling, mediation, negotiation. On the one hand there is a great need at grassroots to teach people the skills needed to resolve their own conflicts in a peaceful, non-violent way. On the other hand an understanding of reconciliation that includes justice for all is essential. The ERJ has provided a vehicle to accomplish this.

In 1993 the churches were again challenged to become more concretely involved in the implementation of the National Peace Accord. The churches needed to press hard for the changes necessary to this venture: for a greater number of women and black leaders to be involved in the processes and structures of the National Peace Accord as well as to lobby government for a massive increase of public money to support the process. Many different South African churches, men and women from different religious organisations, and international ecumenical monitors were indispensable to the national, regional, and local peace structures. There is little doubt that the ecumenical peace monitoring task force, EMPSA, established by the South African Council of Churches with the help of overseas ecumenical partners, had an important role to play as part of the wider monitoring task force.

In the difficult period of transition in the years 1990-1994 various areas in South Africa were especially badly affected by ongoing violence. One of the areas most affected was KwaZulu/Natal. Among the many ventures organised by different churches to counter the violence both in this region and elsewhere, several could be mentioned, however, one of them, Diakonia, to a large extent reflected the general attitude of these ventures. Apart from its ongoing programmes, Diakonia promoted the peace process in KwaZulu/Natal in a number of ways:

- $\quad$ participating in the Natal Church Leaders' Group that was established to help the church find a common response to the violence; 
- promoting the National Peace Accord and encouraging the church to become involved in local and regional dispute-resolution committees;

- helping to monitor violence by participating in the Network of Independent Monitors (NIM) and by assisting the Ecumenical Monitoring Programme in South Africa (EMPSA) which brought international church monitors to KwaZulu/Natal;

- training church people to play a role in peace making;

- helping to provide resources to victims of violence;

- informing members of the trends of violence;

- participating in the KwaZulu/Natal Hostel's Initiative which seeks to upgrade hostels and thus avoid a repetition of the violence in the Transvaal.

In the fields of justice, reconciliation, peacemaking, and countering violence many church and other bodies were set up throughout South Africa, each with its own specific emphasis or geographical focus. They assisted local or regional justice or peace committees which were established, for instance, on the foundations of the National Peace Accord. There are far too many to mention so four will be singled out as examples.

Vuleka Trust was established in 1974 as an ecumenical educational venture focusing on justice and reconciliation. It operated primarily in KwaZulu/Natal which was under- resourced, poverty stricken, and conflict ridden. Vuleka offered programmes and courses to empower people through the acquisition of interpersonal skills to enable them to respond creatively to themselves, others, and their environment.

The National Initiative for Reconciliation (NIR) was founded in the 1980s. Its vision was to create new South Africans for a new South Africa in which the value of life is acknowledged. It sought to help Christians to recognise and confront alienation and to equip them with the skills needed to bring about true reconciliation. Christian involvement in the following four areas are crucial: violence and the peace process; the lost generation of (black) youth; economic justice for all; and democracy. The Pietermaritzburg Agency for Christian Social Awareness (PACSA) was an independent Christian organisation committed to involving the local Pietermaritzburg Christian community in the promotion of human rights and justice issues. It planned to involve the local church in sustainable and empowering development while seeking to foster wholeness in Church and society. This work for justice and peace was achieved through facilitating research, analysis, education publications, action, and spiritual reflection. 
In October 1992 the Network of Independent Monitors (NIM) was launched in an attempt to address the problem of a lack of networking between violence monitors and monitoring organisations. Its major aim was to improve the effectiveness of independent monitoring by strengthening recognition, identity, and the status of monitoring. A code of conduct was drawn up to commit monitors to principles of the UN Declaration of Human Rights and the African Charter. A priority was set to train church volunteers in observation-type monitoring of political funerals, rallies, et cetera. This gave concerned individuals an opportunity to contribute to the peace process.

Historically the South African elections of 1994 will be viewed as South Africa's greatest watershed. A week before this event it seemed as though South Africa was heading for a civil war and general decline; then in a staggering, almost breathless turnaround the people of South Africa collectively and democratically lurched in the direction of a relatively stable future. The Equal Opportunity Foundation with trustees like Archbishop D Tutu, Dr A Boesak, Dean Colin Jones, and Archdeacon M Xundu called on all South Africans to join them from Friday 22 April to Sunday 24 April (three days before the elections) for a time of reflection, contemplation, and forgiving so that the healing process could begin.

This Foundation was committed to assisting in the reconstruction of South Africa and its members believed that the nation's covenanting and bonding together cannot take place without first creating a climate in which all wounds, hurts, fears, and resentments can be given a chance to heal. Early in 1994, in a call for prayers during the period of transition, the CharismaticEvangelical Dialogue for Justice and Transformation (CEDJT) together with the National Initiative for Reconciliation (NIR) and Concerned Evangelicals (CE) provided guidelines for an increased focus on and clarification of the prayer agenda. Apart from affirming God's sovereignty, thanksgiving, repentance, and commitment, a Christian's prophetic role were all emphasised. The focus of prayers, issues, and attitudes needed for a peaceful, democratic, and just outcome as well as those attitudes and issues that could lead to civil war were identified. Issues that require prayer are hope, repentance, tolerance, righteousness, integrity, justice, and dignity. Prayers should also be offered to negate selfishness, intolerance, apathy, injustice, fear, ignorance, hatred, anger, intimidation, insecurity, revenge, alienation, immorality, corruption and godlessness. (Hofmeyr 1994: 110-129).

To describe the first democratic and non-racial elections in South Africa's history as something of a miracle without becoming too euphoric is difficult. The elections had to do with past and future; with ending an era of oppression and beginning an era of possibilities and freedom. Tsele stated 
that on a theological level "the elections were an affirmation of the humanity of those whom apartheid had dehumanised." He adds that the elections were more than party political; in a sense no political party won, the country as a whole won. The elections were about more than party manifestos. "We have entered the dimension of a religious calling. These elections are more than mere justice."

The message at the presidential inauguration of the prisoner turned president, Nelson Mandela, was very clear: "We enter into a covenant that we shall build a society in which all South Africans, both black and white, will be able to walk tall, without any fear in their hearts, assured of their inalienable right to human dignity - a rainbow nation at peace with itself and the world." In an almost religiously inspired spirit of reconciliation he continued: "The time for the healing of the wounds has come. The moment to bridge the chasms that divide us has come. The time to build is upon us."

During the four years, 1990-1994 both the black and white communities displayed an extraordinary tough-mindedness, amid terrible violence, in resisting appeals to bloodshed, and have gone faithfully about their business while their leaders talked and talked and talked. This extraordinary display of courage, of tough moral fibre, held out hope for the future. It had, to a large extent, impressed and even awed the rest of the world.

In the course of Christian history, the church (and that includes mainline churches) and society have, for better or for worse, greatly influenced each other. The church has not existed in a vacuum, but has played a vital interactive role. When it comes to the period 1990 to 1994 in South Africa most people judge the interaction of church and society to be largely positive. Though South African society is strongly shaped in religious terms and has a strong religious base, the interaction was always positive.

Between 1990 and 1994 religious involvement was of such a nature that the churches kept a critical distance whilst remaining involved. The church history of these four years has a relatively positive and strong message for the future, not only for South Africa but also for the whole world. The level of moral leadership from both men and women that has been reached through the involvement of the churches in South Africa is envied by many. This could also encourage Christians on a global scale in the decades to come.

The mainline churches also have a major role in development strategies. Whilst the government has a duty to uplift the people, all communities, including the most underprivileged, can do something to improve their life. The people of the post-apartheid South Africa should not only look to the government for all forms of development, but should realise 
their destiny is in their own hands. The church can provide enlightenment and moral support.

A massive effort to improve quality of life will have to be made in the field of education. Although the churches in South Africa for instance had always played a major role in education, the rise of apartheid forced the churches' involvement in this area to decline. The focus now should be broad and it should include the education of children, adults, and even communities to help them acquire skills to earn a living and promote confidence and dignity. The future can be built with great confidence on the foundations of the pre-apartheid Lovedale, Healdtown, Kilnerton and Rosettenville institutions for education and on a few of the recently established schools like St Mark's in Sekhukhuneland and St Gregory's in the Natal Midlands.

Another important area of interaction between church and society is to increase the social strength of the people and society. South African pastors and theologians were being challenged to complement the government's Reconstruction and Development Programme with programmes of moral reconstruction and spiritual development. Barney Pityana of the Cape Town Research Institute on Christianity refers to this in a thought-provoking article: "In order to live together in a community we must respect one another in our differences and our similarities. We need to recognise that we need one another, we are interdependent. Unless we work together and try to build up a new moral community together, we will soon have no community at all. The African moral principle of "ubuntu" will have to become something more than a mere catch-phrase" (Pityana 1994:6-7). Much hope has, for instance, been invested in the churches in South Africa. What they do and say is important to South African society. Many people are looking to the churches to provide the shared values on which to build a new South Africa. Hopefully all the churches in South Africa will continue preaching the full message of love, forgiveness, reconciliation, and hope.

In South Africa the stagnation of the mainline churches like the Dutch Reformed, Wesleyan Methodist, Congregational and Lutheran churches already began in the 1920's around the same period that saw a rise in subscribers to the Catholic faith. On the other hand the more independent churches as a group was rising exponentially. A possible explanation could be that the independent churches created the mental space to experiment with the Christian message at a time when the Bible was the only message that the apartheid state was prepared to allow to be freely disseminated.

Therefore, Pentecostalism most probably became a spiritual space that assumed a political character that the state did not bother to police very closely because they assumed the majority of its members were illiterate and unschooled, which was not always the case. However late it may seem, a 
trend has been established, for instance, in South Africa that shows that the influence of mainline churches on the black Christian community has also been diminishing since the 1970's. This trend according to J Hendriks and M Froise goes back to the end of the 70 s and the beginnings of the $80 \mathrm{~s}$. This was when black activists were waging the struggle against apartheid, which was then at its peak.

\section{CONCLUSION}

In summary, some contexts are more salient because a church is more protected in the adoption of politically risky postures and more protected from the local subversion factor. These are advantages according to Freston stemming from social position and sociological type rather than theological factors. In Africa the actual performance of mainline churches does not always reflect these advantages. The Catholic Church is more heavily missionarymanned and foreign-funded, and this is crucial for its socio-political influence. Yet it and other mainline denominations have usually needed a threat to their institutional interests before opposing regimes.

Many mainline churches have supported far more years of authoritarian rule in independent Africa than other churches. A good example is for instance Liberia where it was the mainline churches who supported a century of True Whig rule, who asked the United States to intervene militarily in 1990, who could not speak out against the regime in Monrovia because many of their members lived at the mercy of Charles Taylor, and whose generally fatalistic approach paved the way for catastrophe. According to Kalu, in West Africa, mainline churches have grown in numbers due to the resilience of their different strategies. They have been using new forms of charitable institutions to respond to the challenge of poverty. They have been developing internal structural changes in ministerial formation, liturgy and vernacularisation of doctrine. Many of them have allowed charismatic ministries as a means of both theological reformation as well as encapsulation strategy.

New forms of ecumenism have mobilized resources and political clout above all, cultural policy has shifted significantly to root the message in the soil. Of course, traditionalism splits and virulent church politics have smeared the face of Christ in many places. Civil war and coups in Liberia and Sierra-Leone, and military dictatorships in Nigeria are other adverse forces.

(Kalu 2002:254 ff)

The increased evangelical thrust into Muslim states such as Guinea, Gambia, Ivory Coast and Senegal to mention just a few in Africa, merit further attention. 
Similarly, the growth pattern among mainline churches shows wide regional differentiation. In South Africa, for instance, support currently grows for African churches and the prosperity gospel while mainline Protestant and Catholic and formerly segregated denominations are waning. Church attendance figures among whites are dropping while increasing among blacks. This is partly due to white society becoming more secular, following the trend in Europe and to what is seen as a growing cynicism of religion among white Pentecostal churches on the other hand have lately seen their number of young and affluent congregants rise thanks to a large extent to their image of being trendy and fashionable. African Independent Churches like for instance the Zion Christian Church and the Shembe Nazareth Church are gaining ground among the poor and ill because of their emphasis on God's healing power.

Pentecostal political practice has become more social activist in many parts of Africa and show four interlocking grooves: (i) "the rebuilding of the individual", that is the power to be truly human; (ii) a "call to social activism", that is an attack on socio-political structures; (iii) "the rule of saints", that is politics of engagement; and (iv) "the new Israel", that is empowerment and foretaste of the new order. It thus breaks the dichotomy of individual/society private/public, weaving a multifaceted and holistic response to the human predicament in the African ecosystem, using the resources of the gospel.

In his fascinating and excellent book Power, poverty and prayer Kalu (2000) focuses on the role Christianity and therefore the mainline churches and the more independent churches play in African political and socioeconomic life. Colonialism is over but the drums of liberation are still throbbing. Kalu argues that Christianity paved the way for colonialism, but also produced the new champions of independence. He attempts to provide answers to the question what role Christianity has played towards the second liberation of the African continent. Within the post second liberation society in Africa it becomes important to find out which groups or individuals still define themselves as Christian within the new society. We will have to determine what is making the universal church so popular among the working class. Perhaps it is a matter of religion being a thing that gives people a sense of relief from their everyday struggles with or against the powers of secular authority. It is, therefore, understandable that the church allows believers the space to organize themselves under the power of their beliefs (Kalu 2000).

The question finally must be asked what can be done also by the churches about the malaise that afflicts so much of the African continent and which has given it such a bad reputation. The problem is that Africa' $s$ hopelessness is sometimes so widely perceived that it has become a selffulfilling prophecy, deterring investors from creating the new enterprises that might arrest its downslide and causing a continuous brain drain with 
thousands of African professionals and other enterprising spirits abandoning the continent annually. Somehow this vicious cycle must be turned around so that Africa's people can begin to regain their self-confidence through role models of achievement and success. This core idea that Africa should cease to look outside for help later found a new expression in Thabo Mbeki's concept of "an African Renaissance".

\section{Works consulted}

Bediako, K 1995. Christianity in Africa: The renewal of non-western religion Maryknoll, NY: Orbis.

De Gruchy, J W 1995. Christianity and democracy. Cambridge: Cambridge University Press.

Elphick, R \& Davenport, R 1997. Christianity in South Africa: A political, social and cultural history. Cape Town: D Philip.

Freston, P 2001. Evangelicals and politics in Asia, Africa and Latin America. Cambridge: Cambridge University Press.

Gifford, P 1992. New dimensions in African Christianity. Nairobi: All Africa Conference of Churches.

Hastings, A 1970. History of African Christianity 1950-1975. Cambridge: Cambridge University Press.

Hofmeyr, J W 1994. Christianity in the South African context. Studia Historiae Ecclesiasticae 20 (2), 110-129.

Hofmeyr, J W \& Pillay, G J 1994. History of Christianity in South Africa. Pretoria: HAUM.

Hofmeyr J W \& Vorster, W S 1994. New faces of Africa. Pretoria: Unisa.

Hutchinson, M \& Kalu, O (eds) 1998. A global faith. Sydney: CSAC.

Kalu, O U 2000. Power, poverty and prayer: The challenges of poverty and pluralism in African Christianity 1960-1996. Frankfurt: Peter Lang.

Kalu, O U 2002. "Jesus Christ, where are you? Themes in West African church historiography". Missionalia 30(2), 235-264.

Kalu, O U 1998. Tools of hope: Stagnation and political theology in Africa 1960-1995, in Essays on evangelicalism and globalization, 198-201. Sydney: CSAC.

Pityana, B 1994. The urgent need for moral reconstruction. Challenge, 6-7.

Ross, K 1999. God, people and power in Malawi: Democratization in theological perspective. Blantyre: CLAIM.

Sanneh, L 1993. Encountering the West. Maryknoll, NY: Orbis.

Sundkler, B \& Steed,C 2000. A history of the church in Africa. Cambridge: Cambridge University Press. 